\title{
Quantitative morphological variation in Sagitta setosa Müller, 1847 (Chaetognatha) and two closely related taxa
}

\author{
Katja T.C.A. Peijnenburg ${ }^{1}$ and Annelies C. Pierrot-Bults ${ }^{2}$ \\ ${ }^{1}$ Institute for Biodiversity and Ecosystem Dynamics, Faculty of Science, University of Amsterdam, P.O. \\ 94062, 1090 GB Amsterdam, The Netherlands, e-mail: peijnenburg@science.uva.nl; ${ }^{2}$ Zoological Museum \\ Amsterdam, University of Amsterdam, Mauritskade 57, 1092 AD Amsterdam, The Netherlands, e-mail: \\ pierrot@science.uva.nl
}

Keywords: Sagitta setosa, Chaetognatha, morphological variation, European seas

\begin{abstract}
This paper reviews the quantitative morphological variation published for Sagitta setosa Müller, 1847 and two other species described within the $S$. setosa-complex, viz., $S$. euxina Moltschanoff, 1909 from the Black Sea, and S. batava Biersteker \& Van der Spoel, 1966 from the Scheldt Estuary (Netherlands). Data on total (body) length, caudal length, numbers of teeth and hooks, ovary length, and dimensions of fins are compared between these three taxa. Additionally, samples from the North Sea, Mediterranean, and Black Sea are compared to look for geographic differences. Specimens from the Mediterranean were smallest with relatively long caudal segments, and few teeth and hooks, whereas specimens from the Black Sea were largest with relatively short caudal segments and many teeth and hooks. Specimens from the North Sea were intermediate with regards to these characters, but ranges overlapped and there were no obvious differences in allometry. These differences may be ecophenotypic, as the warm and salty Mediterranean Sea and cool and brackish Black Sea are at opposite ends of the environmental spectrum. The dimensions related to the fins showed clearer distinction between samples from different geographical areas, and slight differences in allometry. However, few data were available and little is known about the variance within each geographical area. We found more variation in quantitative characters within $S$. setosa from different parts of its range than between $S$. setosa and either $S$. batava, or $S$. euxina. Sagitta batava conformed to $S$. setosa in terms of all the morphological characters considered. The data for $S$. setosa derived from Biersteker \& Van der Spoel (1966) were atypical and were found to be based on misidentifications of $S$. elegans. Therefore, we concluded that $S$. batava cannot be considered a separate taxon. For $S$. euxina, the data were inconclusive. Quantitative data completely overlapped between $S$. setosa from the Black Sea and $S$. euxina, but few data of $S$. setosa from the Black Sea were available. Because samples were either composed entirely of $S$. setosa or S. euxina (depending on sampling season and depth) and there was a large variation in body lengths and relative ovary lengths, we consider it possible that these samples represent seasonal variants of one and the same species.
\end{abstract}

\section{Contents}

$\begin{array}{ll}\text { Introduction } & 305 \\ \text { Material and methods } & 306 \\ \text { Results and discussion } & 307 \\ \text { Total length and caudal length } & 307 \\ \text { Meristics } & 309 \\ \text { Óvary length } & 310 \\ \text { Fins and dimensions } & 311 \\ \text { Conclusions } & 312 \\ \text { Acknowledgements } & 313 \\ \text { References } & 313\end{array}$

\section{Introduction}

The first drawing of a chaetognath appears to be that of Sagitta setosa drawn by Martinus Slabber (1778) who had fished these so-called 'remarkable sea-worms' or 'Sagitta' out of the inlet waters of Zeeland (Netherlands) on the 10th of July 1768. He could probably not have imagined that over 200 years later there would still be active discussion about the taxonomy of 'his' worms, both in relation to other animal phyla, as well as within the group itself.

Chaetognaths, arrow worms, comprise a small marine phylum of carnivorous invertebrates, ranging in size from 2-120 mm (Bone et al., 1991). About 80 planktonic and 20 benthic species are currently known (Pierrot-Bults, 1997). A striking feature of the phylum is the almost invariable body plan, even though extant species have a wide distribution and depth range. Chaetognaths appear to be morphologically constrained by their environment and mode 
of life. This conservatism in body shape, however, may hide cryptic species, so that detailed analyses of morphological and genetic variation may uncover more species than are currently recognized (PierrotBults \& Van der Spoel, 2003). Particularly in the neritic environment, which is more heterogeneous than the oceanic environment and where species are more subject to geographic isolation, differentiation is expected to be greater (Pierrot-Bults, 1997).

Sagitta setosa is a neritic species with a disjunct distribution over the continental shelf areas in the northeast Atlantic, Mediterranean, and Black Sea (reviewed in Furnestin, 1979). The species is typically associated with waters of reduced salinities in the respective areas (Furnestin, 1938; Fraser, 1949; Furnestin, 1958b; Hecq et al., 1975), but it can tolerate a wide range of environmental conditions (Table 1). Morphological variation has been reported within $S$. setosa from different areas (RitterZáhony, 1911a; Furnestin, 1958a; 1958b; Dallot, 1978; Andréu and Reira, 1990); even so, the species can be clearly distinguished from all other species (Pierrot-Bults \& Chidgey, 1988; Fig. 1). Two other species, closely related to $S$. setosa, have been described, viz., S. euxina Moltschanoff, 1909 from the Black Sea and $S$. batava Biersteker and van der Spoel, 1966 from the Scheldt Estuary and the southern North Sea. The taxonomic status of these species remains unclear. Furnestin (1958b) considered $S$. euxina to be a larger variety of $S$. setosa while Winogradow (1933), Elian (1960), and Alvariño (1965) considered it a valid species. In the most recent revision of the phylum (Bieri, 1991), $S$. euxina is considered to be an intraspecific variety of $S$. setosa, but $S$. batava is placed into a different genus from $S$. setosa, namely Mesosagitta ( $S$. setosa is placed in the new genus Parasagitta, however this nomenclature is not widely accepted and therefore not used here). A pilot study at the Zoological Museum in Amsterdam in 1969 revealed that the range of variation in caudal length of $S$. batava, the character most clearly distinguishing $S$. setosa from $S$. batava (Biersteker \& Van der Spoel, 1966), falls within the known variation described for $S$. setosa (unpublished data). Consequently, $S$. batava was considered to be an intraspecific variant of $S$. setosa by Pierrot-Bults (1976) and Van der Spoel \& Heyman (1983). Pierrot-Bults
Table 1 . Ranges of salinity and average sea surface temperatures (for winter and summer, respectively) in the three major distribution areas of Sagitta setosa (based on data from Zenkevitch, 1963; Becker \& Loewe, 2000; Walday \& Kroglund, 2002; Zenetos et al., 2002, and Zaitsev et al., 2002), and maximum total length and minimum length of mature $S$. setos $a$ as reported by Furnestin (1958b).

\begin{tabular}{lrrll}
\hline & $\begin{array}{l}\text { Salinity } \\
(\%)\end{array}$ & $\begin{array}{l}\text { Temperature } \\
\left({ }^{\circ} \mathrm{C}\right)\end{array}$ & $\begin{array}{l}\text { Max. total } \\
\text { length } \\
(\mathrm{mm})\end{array}$ & $\begin{array}{l}\text { Appearance } \\
\text { of mature } \\
\text { individuals } \\
(\mathrm{mm})\end{array}$ \\
\hline Mediterranean & $36-39$ & $14-23$ & 12 & 8 \\
North Sea & $25-35$ & $6-15$ & 14 & 10 \\
Black Sea & $<10-24$ & $7-14$ & 19 & 13 \\
\hline
\end{tabular}

(1976) suggested that $S$. setosa, $S$. euxina, and $S$. batava comprise a single complex that needs further study. This paper reviews the available literature to compare the variation in morphological characters (mostly quantitative) of these three taxa from different localities. The aims of this paper are to provide an overview of the morphological variation of $S$. setosa within its distribution range and to resolve the taxonomic status of $S$. batava and $S$. euxina.

\section{Material and methods}

Quantitative morphological data from three taxa and three European basins, using morphological characteristics depicted in Figure 1, were obtained from ten different studies (Table 2). Total length (T.L.) and length of the caudal segment (C.L.) were recorded in all studies. However, data on ovary length (O.L.), relative positions of the fins (distance between ventral ganglion and anterior fin, V.G-A.F., and seminal vesicles and caudal fin, S.V.-C.F.) and numbers of teeth and hooks were not always recorded (Table 2). All lengths of morphological structures were expressed as percentages of total length for a certain length class. Therefore, two interdependent variables are being compared and correlations may consequently be exaggerated or spurious (Bookstein et al., 1985). Other studies on morphological variation within S. setosa (Dallot, 1978; Andréu \& Riera, 1990) reported only summary 


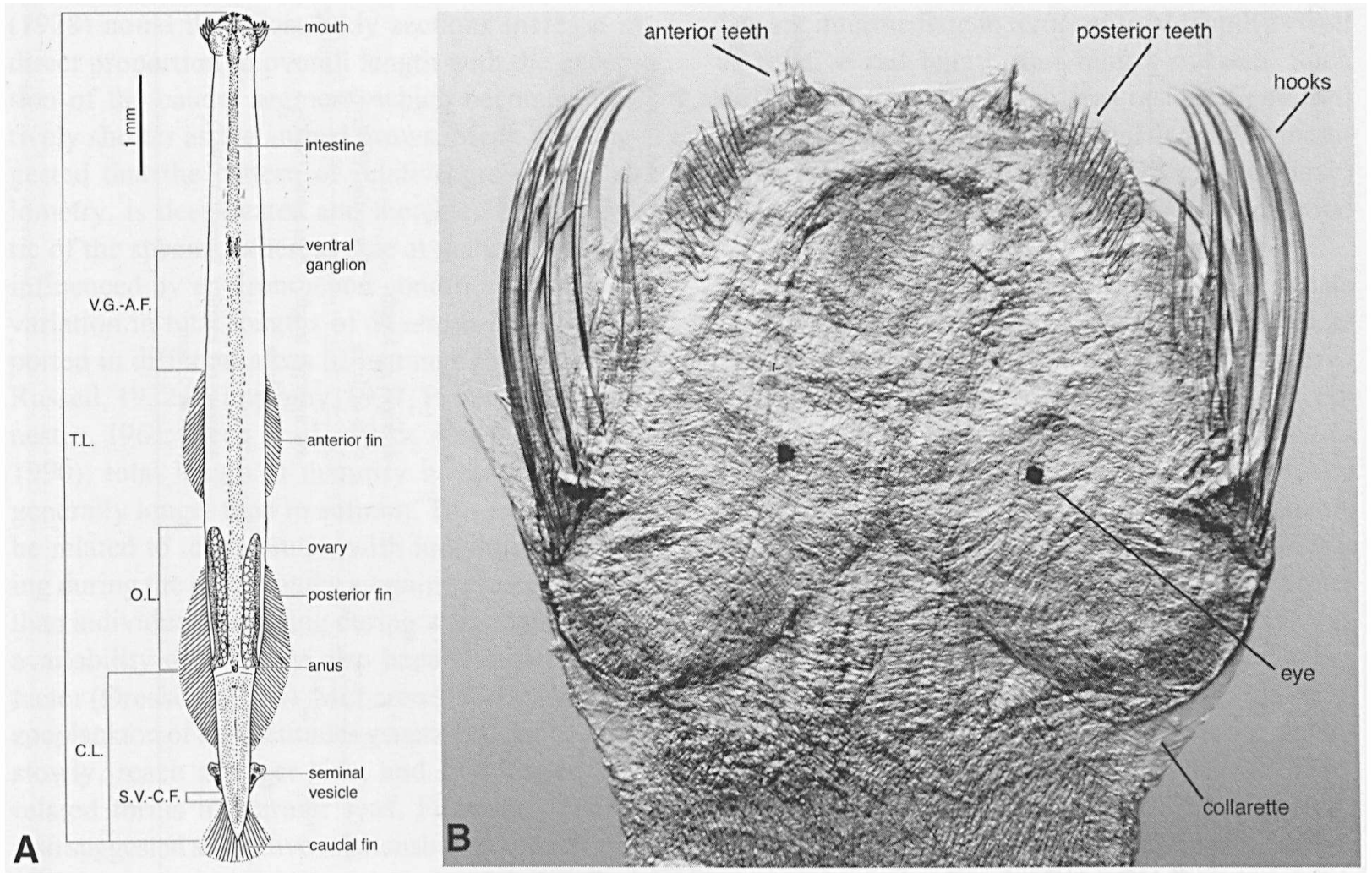

Fig. 1. Morphology of Sagitta setosa. (A) Ventral view of the body with recorded morphological measurements indicated as T.L. (total length), C.L. (caudal length), O.L. (ovary length), V.G.-A.F. (distance between ventral ganglion and anterior fin), and S.V.-C.F. (distance between seminal vesicles and caudal fin; drawing from Pierrot-Bults \& Chidgey 1988). (B) Dorsal view of a head of $S$. setosa from the Celtic Sea (northeast Atlantic), with different types of head armature and other characters indicated.

statistics and could therefore not be included herein. Different data formats were used: ranges per length class, averages per length class, and individual data (Table 2). The individual data format is the most accurate, but unfortunately original datasets could not be retrieved. Therefore, it was not possible to carry out any statistical tests on the data. Instead, we plotted all available data for a certain taxon or geographical area and connected the extreme data points to represent the range of morphological variation reported. For compárison, individual data or averages per length class of specific studies not included in the ranges, were plotted on top of these ranges. Preservation methods of the samples were not always reported. Ritter-Záhony (1911a) used alcohol-preserved specimens for his measurements and Baldasseroni (1914), Scaccini \& Ghirardelli
(1941), and Ghirardelli (1952) used formalin-preserved samples and/ or living material. Different preservation techniques may result in different levels of shrinkage of chaetognaths (Conway \& Robins 1991) and may therefore be a source of error in this comparative study. Additional information on sampling localities, dates, and numbers of specimens analysed (if reported) are indicated in Table 2.

\section{Results and discussion}

\section{Total length and caudal length}

An increase in length with progressing stages of maturity is generally observed in chaetognaths. Meek 


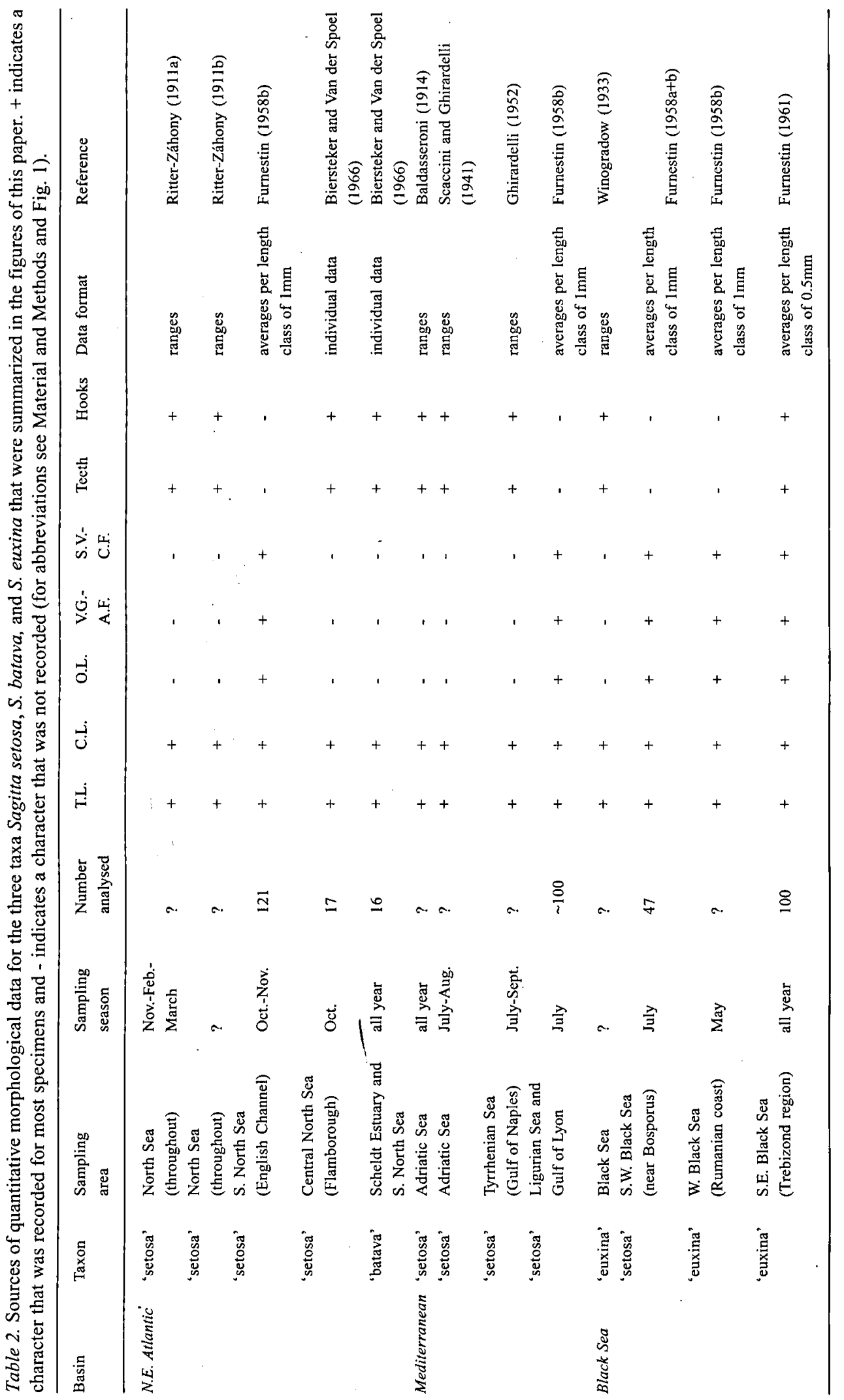


(1928) noted that most body sections increase in direct proportion to overall length with the exception of the caudal segment, which becomes relatively shorter as the animal grows. Meek also suggested that the pattern of relative growth, or allometry, is deep-seated and therefore characteristic of the species, whereas size at maturity is often influenced by environmental conditions. Seasonal variation in total lengths of $S$. setosa has been reported in different areas of its range (Meek, 1928; Russell, 1932; Wimpenny, 1937; Pierce, 1941; Furnestin, 1961; Hecq et al., 1975; Andréu \& Riera, 1990 ); total length at maturity in early spring is generally longer than in autumn. This is thought to be related to temperature, with individuals maturing during the cold months attaining greater lengths than individuals maturing during warm months, but availability of food has also been mentioned as a factor (Øresland, 1986). McLaren (1966) stated that zooplankton of high latitudes generally develop more slowly, reach a larger size, and live longer than related forms in warmer seas. Furnestin (1958b) also suggested a negative relationship between length of $S$. setosa and temperature, based on her data from three different basins (Table 1). Development of chaetognaths is continuous without abrupt changes, although the term 'larva' is used for the very early stages (Pierrot-Bults \& Chidgey, 1988). Several maturity classification schemes for chaetognaths exist (reviewed in Pearre, 1991) but maturity stages of the specimens used in this study were seldomly reported. There is little concensus about the number of annual breeding cycles of S. setosa in different parts of its range. For the North Sea, between one and six generations per year have been suggested (reviewed in Pearre, 1991), for the Black Sea, Besiktepe \& Unsal (2000) proposed a single breeding season in which two broods are produced, and for the Mediterranean Sea, the number of breeding cycles is unknown. However, Dallot (1968) found that $S$. setosa in captivity under optimal conditions matured rapidly, in one to three days.

A negative correlation between percentage tail length of total length and total length can be observed in Figure 2. Specimens from the Mediterranean are generally the smallest, with relatively long tails, whereas those from the Black Sea are the largest with relatively short tails; specimens from the Nörth
Sea are intermediate in terms of total length as well as relative tail length, but ranges overlap. Such differences may well arise as a result of environmental differences, because total length at maturity is affected by temperature (as discussed above) and tail length is negatively correlated with total length.

Comparing Biersteker \& Van der Spoel's data (1966) with the ranges plotted in Figure 2, it is clear that the data of relative caudal length for $S$. batava fall within the range reported for $S$. setosa from the North Sea. However, their data for S. setosa include some very large specimens $(>14 \mathrm{~mm})$, and these specimens have an allometric relationship atypical of $S$. setosa, namely, that the slope is less steep (Fig. 2). Our re-examination of the samples that were used in the study of Biersteker \& Van der Spoel (1966) showed: 1) that their specimens of $S$. setosa were misidentifications of (juvenile) S. elegans, and 2) that their S. batava specimens corresponded to S. setosa. Furnestin (1958a; 1958b; 1961) reported a lot of overlap between average caudal lengths per size class of $S$. euxina and $S$. setosa from the Black Sea, and considered this character unfit for discriminating between the two taxa. Indeed, her data for $S$. setosa from the Black Sea (plotted in Fig. 2) all fall within the range reported for $S$. euxina.

\section{Meristics}

The number of teeth and hooks increases with age until maturity and then decreases, since some are lost in older animals (Ritter-Záhony, 191 1b; Kapp, 1991). Temperature may also affect the numbers (Ritter-Záhony, 1911a; Tokioka, 1974). Data on the numbers of posterior teeth and anterior teeth are summarized in Figures $3 \mathrm{~A}$ and $3 \mathrm{~B}$, respectively. There is a positive relationship between the numbers of teeth and total length, which is steeper in the case of posterior teeth. There is little overlap between the ranges of Mediterranean and Black Sea specimens, while those from the North Sea are intermediate and overlapping with both. However, the separation of these ranges is mainly the effect of differences in total length. The data for North Sea 'S. setosa' reported by Biersteker \& Van der 


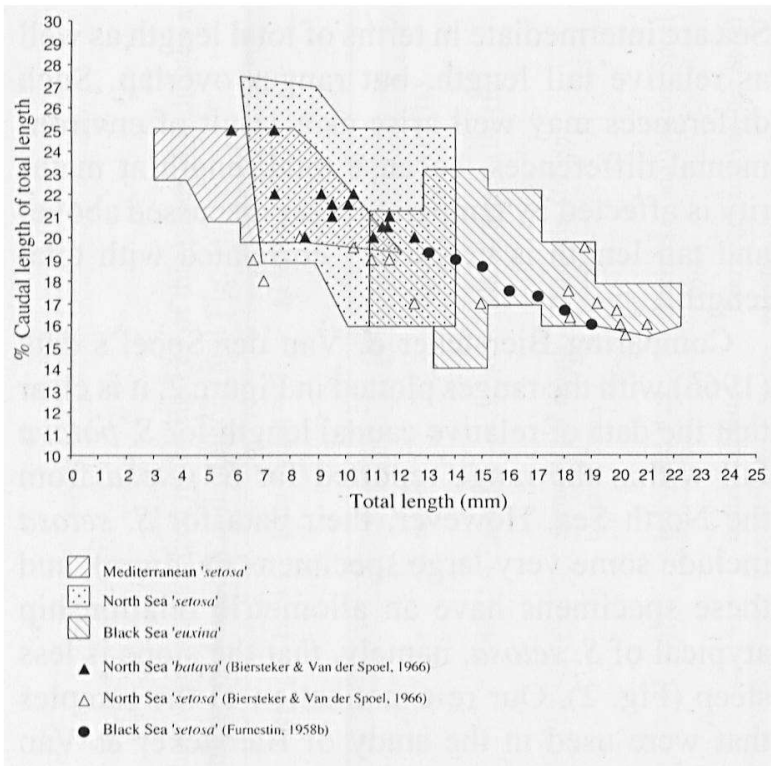

Fig. 2. Percentage caudal length of total length plotted against total length for different taxa from the $S$. setosa-complex from three different basins (for data sources see Table 2). Individual data for ' $S$. batava' and 'S. setosa' are from Biersteker \& Van der Spoel (1966). Datapoints for S. setosa from the Black Sea are averages per size class (from Furnestin 1958b).

Spoel (1966) are typical of S. elegans (as discussed above). Winogradow (1933) and Elian (1960) considered the difference in numbers of posterior and anterior teeth between $S$. setosa and $S$. euxina from the Black Sea important (anterior teeth: 3-8 and 810, posterior teeth: 6-12 and 15-20 for $S$. setosa and $S$. euxina, respectively). However, according to Furnestin (1958b) these differences were mainly the result of length differences, because the $S$. euxina specimens were larger and consequently had more teeth. The numbers of hooks do not, or hardly change in relation to total length, and do not separate specimens or taxa from different localities (Fig. 4)

\section{Ovary length}

Only Furnestin (1958a; 1958b; 1961) recorded ovary length per size class (averages), depicted in Figure 5 , noting a positive relationship between ovary length and total length in most samples, but not for the sample of S. setosa from the Black Sea. Furnestin (1958b) noted that the variation within a single size
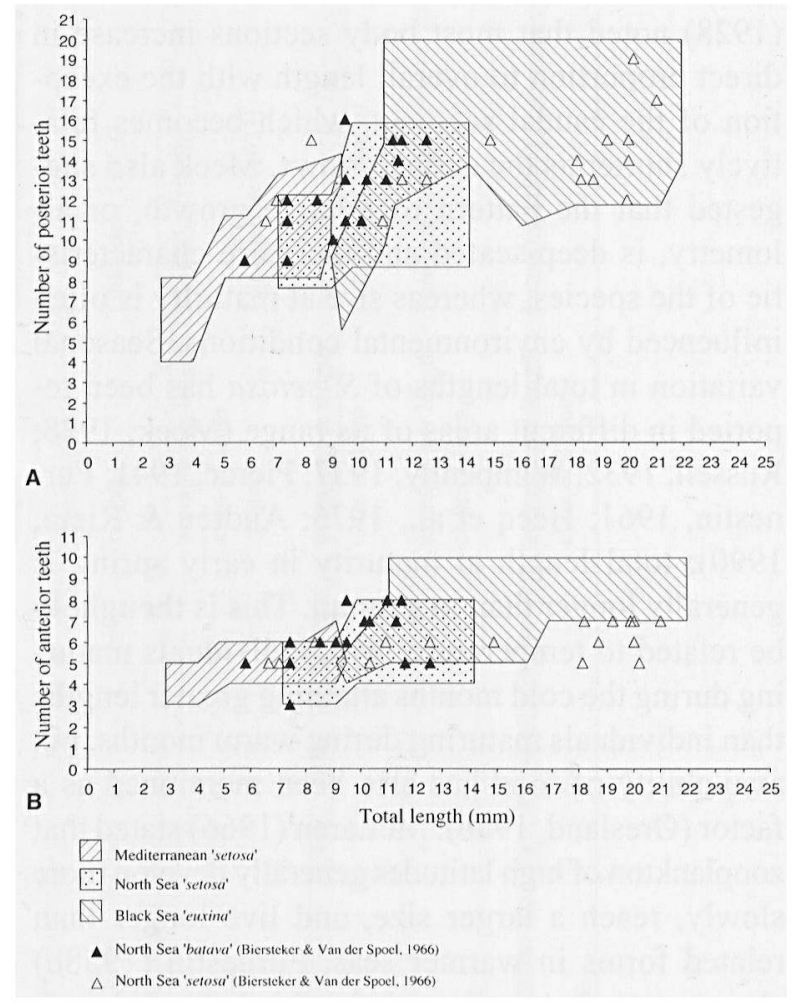

Fig. 3. Number of posterior (A) and anterior (B) teeth plotted against total length for different taxa from the $S$. setosa-complex from three different basins (for data sources see Table 2). Individual datapoints for ' $S$. batava' and 'S. setosa' are from Biersteker \& Van der Spoel (1966).
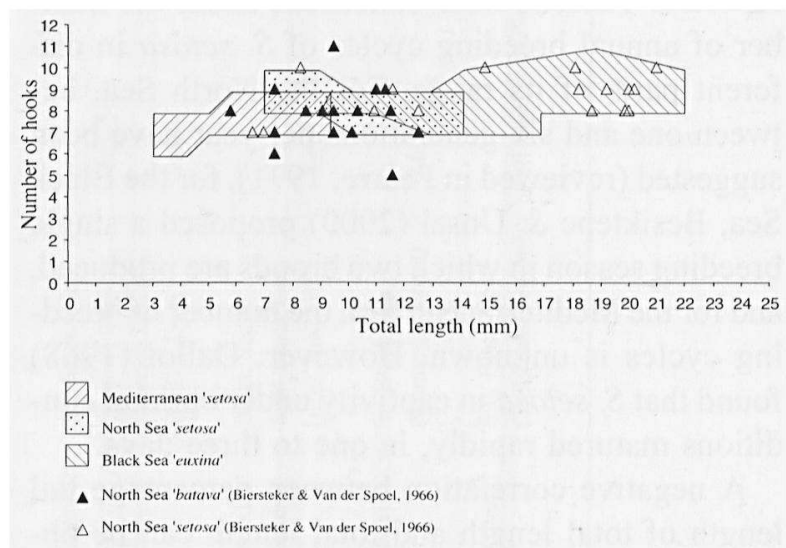

Fig. 4. Number of hooks plotted against total length for different taxa from the $S$. setosa-complex from three different basins (for data sources see Table 2). Individual datapoints for ' $S$. batava' and 'S. setosa' are from Biersteker \& Van der Spoel (1966). 

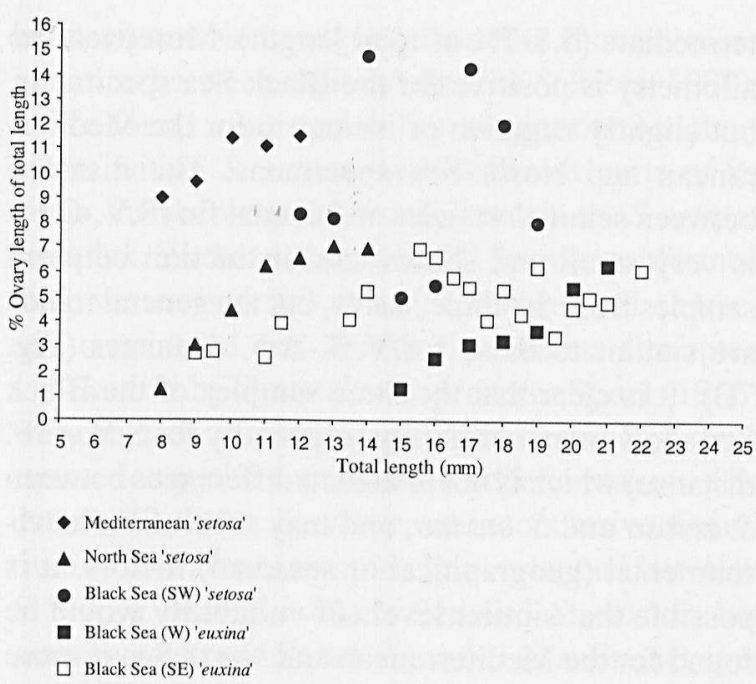

Fig. 5. Percentage ovary length of total length (averages per size class) plotted against total length for different taxa from the $S$. setosa-complex from three different basins (data from Furnestin, 1958a; 1958b; 1961, see Table 2).

class could be very large, especially for samples from the North Sea and Black Sea. However, generally, specimens from the North Sea had relatively shorter ovaries than specimens from the Mediterranean Sea. The 1969 pilot study reported highly variable ovary lengths for specimens from the Scheldt Estuary, varying between 2.1 and 17.4\% of total length (unpublished data). In addition, the holotype of $S$. batava has ovaries extending past the anterior end of the posterior fins $(-17.5 \%$ of total length, Fig. 6A), indicating that specimens from the North Sea may also possess (very) long ovaries.

Clearly, ovary length is highly variable and in the past $S$. euxina and $S$. batava have been associated with the occurrence of multiple maturity cycles (Furnestin, 1961). Especially the case of $S$. euxina and $S$. setosa from the Black Sea is interesting. Elian (1960) stated that $S$. euxina is the larger species in the Black Sea with relatively long ovaries that contain many small eggs (20-30) whereas $S$. setosa, the smaller species, has relatively short ovaries with fewer and larger eggs (6-10, Fig. $6 \mathrm{~B}$ and $6 \mathrm{C}$, respectively). Moreover, ecological differences between the two species have been noted, namely that S. euxina is characteristic of the cold period of the year (November-May) and occurs in deeper layers
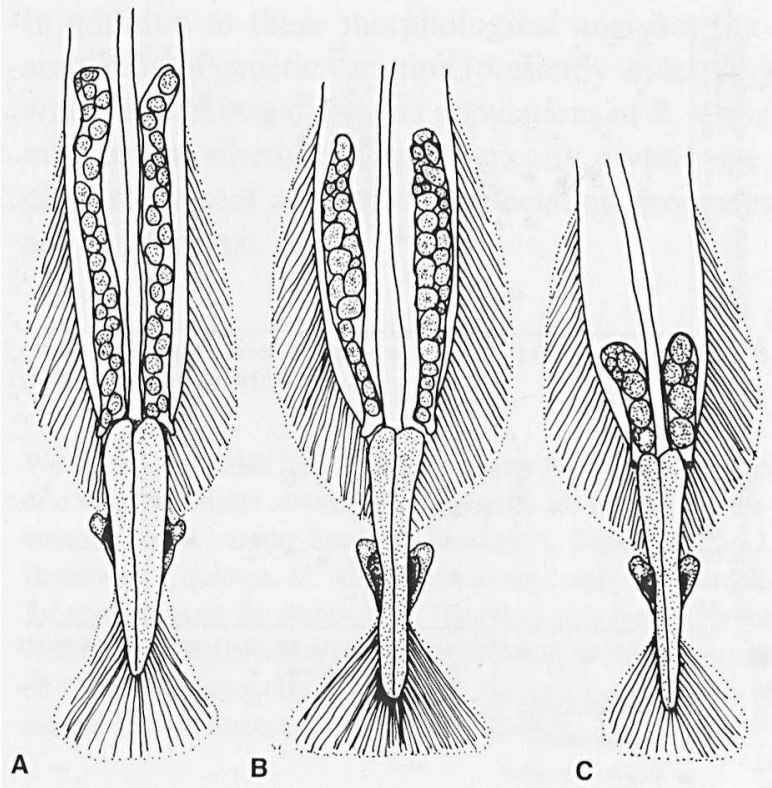

Fig. 6. Posterior ends of the body showing variation in ovary size, and number and sizes of the ova from species (re)descriptions of (A) S. batäva from the Scheldt Estuary (redrawn from Biersteker \& Van der Spoel, 1966), (B) S. euxina from the Black Sea (redrawn from Elian, 1960), and (C) S. setosa from the Black Sea (redrawn from Elian, 1960).

and more at open sea, whereas $S$. setosa is characteristic of the warm period of the year (June-August) and occurs closer inshore and in the upper layers (Winogradow, 1933; Elian, 1960). Interestingly, we found no reports of records from the Black Sea of the two species co-occurring. However, Furnestin (1961) suggested the presence of two maturity cycles based on her data from the Trebizond region (SE Black Sea) in which $S$. setosa may represent the first cycle of this species (individuals $<17 \mathrm{~mm}$ total length), and $S$. euxina the following cycles (individuals $>17 \mathrm{~mm}$ total length, see Figure 5 , open square symbols).

\section{Fins and dimensions}

Fins are delicate structures which are often damaged during preservation. However, fin remains are usually enough to distinguish the beginnings and ends of the fins. Herein, only the distances between ventral ganglion and anterior edge of anterior fins 


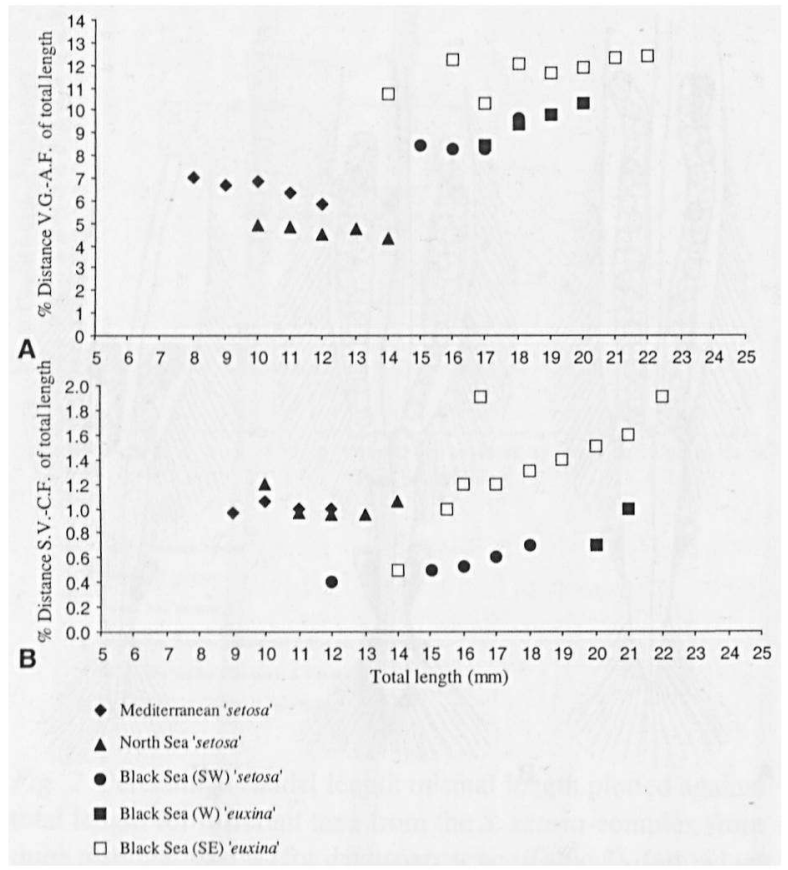

Fig. 7. Average percentage distance between ventral ganglion and anterior fin (A) and average percentage distance between seminal vesicles and caudal fin (B) of total length, plotted against total length for different taxa from the $S$. setosa-complex from three different basins (data are from Furnestin, 1958a; 1958b; 1961, see Table 2).

(Fig. 7A) and between seminal vesicle and caudal fin (Fig. 7B) are compared (other data were not available). Ritter-Záhony (1911a) described varieties of $S$. setosa from the North Sea with considerable differences in anterior fin length and distance between the ventral ganglion and anterior fin. According to Meek (1928), fins are secondary structures that appear late in life (especially the anterior pair), and so are subject to environmentally induced variability, which is apparent not only between regions but also seasonally and annually within the same region (Ritter-Záhony, 1911a; Meek, 1928; Russell, 1932).

The data concerning relative distance between ventral ganglion and anterior fin (V.G.-A.F.) from Furnestin (1958a; 1958b; 1961, Fig. 7A) show greater distinction between samples from the three basins than the other characters mentioned so far. Average V.G.-A.F. distances of Black Sea samples are $>8 \%$ of total length, of North Sea samples $<5 \%$ of total length, and of Mediterranean samples in- termediate (5.8-7\% of total length). Moreover, the allometry is positive for the Black Sea specimens, but slightly negative or isometric for the Mediterranean and North Sea specimens. The distance between seminal vesicles and caudal fin (S.V.-C.F.) is very small and shows less distinction between samples from the three basins, but the general trends are similar to those for V.G.-A.F. distances (Fig. 7B). It is clear that the three samples of the Black Sea show more variability (especially for S.V.-C.F. distance) which is not related to differences between $S$. setosa and $S$. euxina, and may result from environmental (geographical or seasonal) factors. It is possible that similar levels of variability would be found for the Mediterranean and North Sea if more samples from these regions are examined.

\section{Conclusions}

Many of the characters discussed here would appear to be influenced by environmental conditions. A wide range of conditions prevail from the warm and salty waters of the Mediterranean Sea on one hand, to the cold and brackish waters of the Black Sea on the other, with the North Sea exhibiting intermediate conditions. This disparity is reflected in morphological differences between samples of $S$. setos $a$, namely in total length, relative tail length, and numbers of teeth and hooks, though the measured ranges of these characters overlap and there are no obvious differences in allometry. This may indicate that these morphological differences are under ecophenotypic control. Our genetic data differentiate between $S$. setosa populations from the different basins, and show that populations of the Mediterranean and Black Sea are more closely related to each other than to the North Sea (Peijnenburg et al., 2004). This supports the idea that the morphological differences observed between populations from the three different basins are mainly the result of environmental factors. Andréu \& Riera (1990) also concluded that most of the morphological characters they examined were more variable between seasons within a region than between regions (one Mediterranean and two North Sea localities were considered). Only the allometric relationships of caudal length and the distance 
between anterior and posterior fins showed more variation between regions (Andréu \& Riera, 1990).

We found more variability in quantitative characters within $S$. setosa from different parts of its range, than between the nominal taxa in the $S$. setosacomplex. We have shown that $S$. batava conformed to $S$. setosa in terms of all morphological characters considered and that the specimens attributed to $S$. setosa by Biersteker \& Van der Spoel (1966) were in fact $S$. elegans. On this basis, $S$. batava can no longer be considered a different taxon. The data for S. euxina, however, are inconclusive. Quantitative characters completely overlapped between $S$. setosa from the Black Sea and $S$. euxina, but authors who considered $S$. euxina as a distinct species (Winogradow, 1933; Elian, 1960) did not include morphological measurements of $S$. setosa. The only qualitative morphological difference they mentioned is the presence of a (small) collarette in $S$. euxina, which is absent in S. setosa. However, Furnestin (1958b) observed that a small collarette is present in $S$. setosa (see also Fig. 1B) and may sometimes be absent in $S$. euxina. Winogradow (1933) and Elian (1960) further considered the ecological differences between the two taxa very important, and it is noteworthy that Elian (1960) reported samples from the same region in the western Black Sea that are either entirely composed of $S$. euxina and sampled in winter, or entirely composed of $S$. setosa and sampled in summer. This, together with the large variation in total lengths and relative ovary lengths, strengthens the likelihood of a seasonal succession of maturity cycles in the Black Sea corresponding to either $S$. setosa or S. euxina, as suggested by Furnestin (1961). However, more data are needed relevant to the life history of the species in the different geographical areas.

This study shows that a lot of morphological variation exists within S. setosa. However, we consider this variation insufficient to separate the species. More conclusive data about subtle morphological differences require powerful morphometric methods, e.g., multivariate and shape analyses, and should avoid the use of percentages and other derived measures. Moreover, more detailed examination of morphological structures using electron microscopy may reveal species-specific differences, e.g., in the surface structure of teeth and hooks (Kapp 1991).
In addition to these morphological analyses, examination of genetic variation (presently underway) within and between disjunct populations of $S$. setosa may reveal whether morphologically cryptic species are present and whether speciation processes are in progress.

\section{Acknowledgements}

We thank J. van Arkel for help with the figures and the photograph of a head of Sagitta setosa, E. Michel and M. Genner for discussion, and S. van der Spoel, S. Menken, L. Papadopoulos, J. Breeuwer, F. Schram, M. Angel, D. Conway, and E. Ghirardelli for comments on the manuscript. This work was funded by the Netherlands Organization for Scientific Research (NWO) as part of the priority program 'Sustainable use and conservation of marine living resources' (project 885.100.02).

\section{References}

Alvariño A. 1965. Chaetognaths. Oceangr. Mar. Biol. Ann. Rev. 3: 115-194.

Andréu P, Riera T. 1990. Morphometric relationships in the chaetognath Sagitta setosa Müller 1847: within population versus between population variability. Scient. Mar. 54(2): 101-105.

Baldasseroni V. 1914. I Chetognati raccolti nell'Adriatico dalla R.N. 'Ciclope' nelle crociere III-VII. R. Comitato Talassografico Italiano, 38: 3-21.

Becker G, Loewe P. 2000. BSH Hamburg Report. In: The annual ICES Ocean Climate Status Summary 1999/2000. Working group on oceanic hydrography, Turrell $\mathrm{B}$, ed. Available online: http://www.ices.dk/status/clim9900.

Besiktepe S, Unsal M. 2000. Population structure, vertical distribution and diel migration of Sagitta setosa (Chaetognatha) in the south-western part of the Black Sea. J. Plankton Res. 22: 669-683.

Bieri R. 1991. Systematics of the Chaetognatha. In: Bone Q, Kapp H, and Pierrot-Bults AC, eds. The biology of chaetognaths. Oxford Univ. Press, 122-137.

Biersteker RH, van der Spoel S. 1966. Sagitta batava n.sp. from the Scheldt estuary, the Netherlands (Chaetognatha). Beaufortia 167: 61-69.

Bone Q, Kapp H, Pierrot-Bults AC. 1991. Introduction and relationships of the group. In: Bone Q, Kapp H, and Pierrot-Bults AC, eds. The biology of chaetognaths. Oxford Univ. Press, 1-4.

Bookstein F, Chernoff B, EIder R, Hunphries J, Smith G, Strauss R. 1985. Morphometrics in evolutionary biology. Spec. Publ. 15, Acad. Nat. Sci. Philadelphia.

Conway DVP, Robins DB. 1991. Collection and chemical analysis of chaetognaths and changes due to preservation. 
In: Bone $\mathrm{Q}$, Kapp $\mathrm{H}$, and Pierrot-Bults $\mathrm{AC}$, eds. The biology of chaetognaths. Oxford Univ. Press, 137-146.

Dallot S. 1968. Observations préliminaires sur la reproduction en élevage du Chaetognathe planctonique Sagitta setosa Müller. Rapp. Comm. int. Mer Médit. 19: 521-523.

Dallot S. 1978. Sur la présence du Chaetognathe planctonique Sagitta setosa Müller 1847, dans les eaux néritiques de Castellón. Inv. Pesq. 42: 33-52.

Elian L. 1960. Observations systématiques et biologiques sur les chaetognathes qui se trouvent dans les eaux roumaines de la mer noire. Rapp. Comm. int. Mer Médit. 15: 359-366.

Fraser JH. 1949. The occurrence of unusual species of Chaetognatha in Scottish plankton collections. J. Mar. Biol. Assoc. UK. 28: 489-491.

Furnestin J. 1938. Influence de la salinité sur la répartition du genre Sagitta dans l'Atlantique nord-est. Revue des Trav. de l'office des pêches maritim. 11(3): 425-439.

Furnestin M-L. 1958a. Chaetognathes récoltés en méditerranée orientale et en mer noire par la 'Calypso' (campagne 1955 Rapp. Comm. int. Mer Médit. 14: 201-209.

Furnestin M-L. 1958b. Les variations morphologiques de Sagitta setosa Müller et ses rapports avec deux expeces voisines. Rev. Trav. Inst. Pêches marit. 22(2): 211-223.

Furnestin M-L. 1961. Compléments à l'etude de Sagitta euxina variété Sagitta setosa. Rapp. Comm. int. Mer Médit. 16: $97-101$.

Furnestin, M-L. 1979. Aspects of the zoogeography of the Mediterranean plankton. In: Van der Spoel S, PierrotBults AC, eds. Zoogeography and diversity of plankton. Bunge, Utrecht, 191-253.

Ghirardelli E. 1952. Osservazioni biologiche e sistematiche sui chetognati del golfo di Napoli. Pubbl. Staz. Zool. Napoli, 23: 295-312.

Hecq JH, Heyden D, Moermans R. 1975. Biologie de Sagitta setosa dans le pas de Calais et le sud de la mer du Nord. Bull. Soc. Roy. Sci. Liège 44(9-10): 653-661.

Kapp H. 1991. Morphology and anatomy. In: Bone Q, Kapp $\mathrm{H}$, and Pierrot-Bults $\mathrm{AC}$, eds. The biology of chaetognaths. Oxford Univ. Press, 5-17.

McLaren IA. 1966. Adaptive significance of large size and long life of the chaetognath Sagitta elegans in the ardtic. Ecology 47(5): 852-855.

Meek A. 1928. On Sagitta elegans and Sagitta setosa from the Northumbrian Plankton, with a note on a trematode parasite. Proc. Zool. Soc. Lond. 3: 743-776.

Moltschanoff LA. 1909. Die Chätognathen des Schwarzen Meeres. Bull. Acad. Sci. St-Petersburg, ser. 6, 3 (2).

Müller J. 1847. Fortsetzung des berichts über einige neue thierformen der Nordsee. Arch. Anat. Physiol. wiss. Med. 14: 147.

Øresland V. 1986. Temporal distribution of size and maturity stages of the chaetognath Sagitta setosa in the western English Channel. Mar. Ecol. Prog. Ser. 29: 55-60.

Pearre S Jr. 1991. Growth and reproduction. In: Bone Q, Kapp $\mathrm{H}$, and Pierrot-Bults $\mathrm{AC}$, eds. The biology of chaetognaths. Oxford Univ. Press, 61-75.

Peijnenburg KTCA, Breeuwer JAJ, Pierrot-Bults AC,
Menken SBJ. 2004. Phylogeography of the planktonic chaetognath Sagitta setosa reveals isolation in European seas. Evolution 58: 1472-1487.

Pierce EL. 1941. The occurrence and breeding of Sagitta elegans Verrill and Sagitta setosa J. Müller in parts of the Irish sea. J. Mar. Biol. Assoc. UK. 25: 113-124.

Pierrot-Bults AC. 1976. Zoogeographic patterns in chaetognaths and some other planktonic organisms. Bull. zool. mus. Univ. Amsterdam 5(8): 59-72.

Pierrot-Bults AC. 1997. Biological diversity in oceanic macrozooplankton: more than counting species. In: Ormond RFG, Gage JD, Angel MV, eds. Marine biodiversity. Patterns and processes. Cambridge Univ. Press, Cambridge, 69-93.

Pierrot-Bults AC, Chidgey KC. 1988. Chaetognatha, keys and notes for the identification of the species. . Kermack DM, Barnes RSK, eds. Synopses of the British fauna 39, London.

Pierrot-Bults AC, van der Spoel S. 2003. Macrozooplankton diversity: how much do we really know? Zool. Verh. Leiden 345: 297-312.

Ritter-Záhony R. von. 1911a. Die Chätognathen der Plankton-Expedition. Ergebn. Plankt. Exped. Humboldt-Stiftung 2-H.e. 1-32.

Ritter-Záhony R. von. 1911b. Chaetognathi. Das Tierreich 29: 1-34.

Russell FS. 1932. On the biology of Sagitta. II. The breeding and growth of Sagitta setosa J. Müller in the Plymouth area, 1930-31, with a comparison with that of $S$. elegans Verrill. J. Mar. Biol. Assoc. UK. 18: 147-160.

Scaccini A, Ghirardelli E. 1941. I Chetognati del mare adriatico presso Rovigno. Note Ist. Biol. Mar. Rovigno 2: 1-16.

Slabber M. 1778. Natuurkundige verlustigingen behelzende microscopise waarnemingen van in- en uitlandse wateren land-dieren. J. Bosch Haarlem.

Tokioka T. 1974. On the specific validity of species pairs or trios of plankton animals distributed respectively in different but adjoining water masses as seen in chaetognaths. Publ. Seto Mar. Biol. Lab. 21: 393-408.

Van der Spoel S, Heyman RP. 1983. A comparative atlas of zooplankton. Biological patterns in the oceans. Bunge, Utrecht.

Walday M, Kroglund T. 2002. The North Sea, bottom trawling and oil/gas exploitation. In: Künitzer A, ed. Europe's biodiversity, biogeographical regions and seas. European Environment Agency online report: http://reports.eea.eu.int/ report_2002_0524_154909/en/tab_content_RLR

Wimpenny RS. 1937. The distribution, breeding and feeding of some important plankton organisms of the southwest North Sea in 1934. Part 1. Fish. Investig. London Ser. II 15: 2-52.

Winogradow K. 1933. Bemerkungen über Chaetognathen des Schwarzen Meeres. Int. Revue Hydrobiol. 28: 247249.

Zaitsev YP, Alexandrov BG, Berlinsky NA, Zenetos A. 2002. The Black Sea, an oxygen-poor sea. In: Künitzer A, ed. Europe's biodiversity, biogeographical regions and 
seas. European Environment Agency online report: http:/ /reports.eea.eu.int/report_2002_0524_154909/en/ tab_content_RLR

Zenkevitch L. 1963. Biology of the seas of the U.S.S.R. George Allen and Unwin, London.

Zenetos A, Siokou-Frangou I, Gotsis-Skretas O, Groom

S. 2002. The Mediterranean Sea, blue oxygen-rich, nutri- ent-poor waters. In: Künitzer A, ed. Europe's biodiversity, biogeographical regions and seas. European Environment Agency online report: http://reports.eea.eu.int/report_2002_0524_154909/en/tab_content_RLR

Received: 24 November 2003 